\title{
KEBIJAKAN PEMERINTAH DALAM PERLINDUNGAN HAK KEKAYAAN INTELEKTUAL (HAKI) DI INDONESIA
}

\section{Government Policy on Protection Intellectual Property Rights (HAKI) in Indonesia}

\section{Laksminarti*}

Universitas Muhammadiyah Palangkaraya, Palangka Raya, Central Kalimantan, Indonesia

email:

laksminarti@gmail.com

Kata Kunci:

Kebijakan

Pemerintah

Perlindungan

\section{Keywords:}

Policy

Government

Protection

\section{Accepted}

June 2018

\section{Published}

October 2018

\begin{abstract}
Abstrak
Penelitian ini bertujuan untuk memperoleh gambaran mengenai kebijakan di bidang Hak Kekayaan Intelektual serta Peraturan Perundang-Undangan dan Penegakan Hukum Hak Kekayaan Intelektual (HAKI). Semakin derasnya arus perdagangan bebas yang menuntut makin tingginya kreativitas produk yang dihasilkan terbukti semakin memacu perkembangan teknologi yang mendukung kebutuhan tersebut. Seiring dengan hal tersebut mulai disadari akan pentingnya peranan dari Hak Kekayaan Intelektual (HAKI) dalam mendukung perkembangan teknologi. Hal ini terlihat dari semakin tingginya jumlah permohonan Hak Cipta, Hak Paten dan Merek serta cukup banyaknya permohonan desain industri yang ditujukan kepada Direktorat Jenderal Hak Kekayaan Intelektual, Kantor Wilayah Hukum dan Hak Asasi Manusia.

Dengan menggunakan analisis deskriptif diperoleh gambaran bahwa Pelaksanaan system Hak Kekayaan Intelektual yang baik bukan saja memerlukan Peraturan Perundang-Undangan di bidang Hak Kekayaan Intelektual yang tepat, tetapi perlu di dukung pula oleh administrasi, penegakan hukum serta program sosialisasi yang optimal tentang Hak Kekayaan Intelektual (HAKI).

Hasil penelitian menunjukkan bahwa pada saat ini Indonesia telah memiliki perangkat Peraturan Perundang-Undangan di bidang Hak Kekayaan Intelektual yang cukup memadai dan tidak bertentangan dengan ketentuan-ketentuan sebagaimana dipersyaratkan dalam persetujuan TRIPS (Agreement on Trade Releated Aspect Of Intelectual Property Rights). Pada prinsipnya semua peraturan dibidang Hak Kekayaan Intelektual telah disusun dengan memperhatikan kepentingan masyarakat dan selaras dengan ketentuan minimum sebagaimana yang telah dipersyaratkan oleh persetujuan TRIPS (Agreement on Trade Releated Aspect Of Intelectual Property Rights).
\end{abstract}

\begin{abstract}
This research aims to obtain a picture of the policy in the field of intellectual property rights as well as legislation and law enforcement of intellectual Property Rights (HAKI). The increasingly high-flow of free trades that demand the higher creativity of the resulting products proved increasingly spur on the technological developments that support these needs. Along with this, it began to realize the importance of the role of intellectual Property Rights (HAKI) in supporting technological developments. This is seen from the increasingly high number of copyright, patent and trademark applications and the sufficient number of industrial design applications addressed to the Directorate General of Intellectual Property Rights, the Office of the jurisdiction and human rights.

By using a descriptive analysis obtained the idea that the implementation of good intellectual property rights system not only requires the legislation in the field of intellectual property right but should be supported also by Administration, law enforcement and an optimal socialization program on intellectual property Rights (HAKI).

The results of the research show that at this time, Indonesia has had a legal device in the field of intellectual property rights which is adequate and does not contradict the provisions as required in Agreement on Trade-Related Aspect Of Intelectual Property Rights. In principle, all rules of intellectual property rights have been prepared about the interests of the Community and by the minimum provisions as required by TRIPS approval (Agreement on Trade-Related) Aspect Of Intelectual Property Rights).
\end{abstract}





\section{PENDAHULUAN}

Menghadapi Era Perdagangan Bebas dewasa ini dimana gerbang Masyarakat Ekonomi Asean (MEA) dibuka, di tengah-tengah krisis multi Dimensional yang sedang kita hadapi, diperlukan langkah-langkah strategis yang terpadu dan terkoordinasi dengan baik antar Instansi/Departemen bahkan juga antar pemerintah dan dunia usaha untuk merumuskan konsensus nasional sebagai landasan dalam memperjuangkan kepentingan Indonesia di forum Internasional.

Secara garis besar paparan mencakup :

I. Kebijakan dan Kesiapan Indonesia di Bidang Hak Kekayaan Intelektual

2. Peraturan Perundang-undangan dan Penegakkan Hukum Hak Kekayaan Intelektual (HAKI)

Kedua permasalahan tersebut didekati ataupun ditinjau dari aspek Hukum dengan memperhatikan keterkaitannya dengan aspek-aspek lainnya dalam rangka meningkatkan kesiapan Indonesia dalam keikutsertaan Indonesia sebagai anggota WTO (World Trade Organization) ataupun anggota Masyarakat Ekonomi Asean (MEA).

Kesepakatan Indonesia untuk merealisasikan gagasan mengenai ASEAN Free Trade Area (AFTA) serta keikutsertaan Indonesia sebagai anggota World Trade Organization (WTO) dan Asia Pacific Economic Corporation (APEC), Masyarakat Ekonomi ASEAN (MEA), telah menunjukkan keseriusan pemerintah dalam mendukung sistem perekonomian yang bebas dan terbuka dan secara tidak langsung memacu dan memotivasi perusahaan-perusahaan di Indonesia untuk lebih meningkatkan daya saingnya, bukan hanya bersaing dengan produk-produk lokal sesama perusahaan-perusahaan Indonesia namun mau tidak mau harus bersaing keras pula dengan produk-produk perusahaan-perusahaan dunia.
Semakin derasnya arus perdagangan bebas yang menuntut makin tingginya kreativitas produk yang dihasilkan terbukti semakin memacu perkembangan teknologi yang mendukung kebutuhan tersebut. Seiring dengan hal tersebut mulai disadari akan pentingnya peranan dari Hak Kekayaan Intelektual (HAKI) dalam mendukung perkembangan teknologi tersebut. $\mathrm{Hal}$ ini terlihat dari semakin tingginya jumlah permohonan Hak Cipta, Hak Paten dan Merek serta cukup banyaknya permohonan desain industri yang ditujukan kepada Direktorat Jenderal Hak Kekayaan Intelektual, Kantor Wilayah Hukum dan Hak Asasi Manusia.

\section{METODOLOGI}

Pendekatan yang dipakai dalam penelitian ini adalah yuridis normatif. Penelitian ini lebih memfokuskan pada studi kepustakaan. Pendekatan yuridis normatif dimaksudkan untuk mengkaji arti dan maksud dari kebijakan pemerintah dalam perlindungan Hak Kekayaan Intelektual (HAKI) di Indonesia, juga untuk mengkaji peraturan-peraturan yang mengatur mengenai perlindungan Hak Kekayaan Intelektual (HAKI) di Indonesia, mengkaji juga mengenai ketentuan-ketentuan atau kaidah-kaidah Hukum yang berkaitan dengan judul penelitian ini.

\section{HASIL DAN PEMBAHASAN}

\section{Kebijakan dan Kesiapan Indonesia di Bidang Hak Kekayaan Intelektual}

Pemerintah sangat menyadari bahwa Implementasi Sistem Hak Kekayaan Intelektual (HAKI) merupakan suatu tugas yang besar dan perlu mendapatkan perhatian yang serius. Terlebih dengan keikutsertaan Indonesia sebagai anggota WTO dengan konsekwensi melaksanakan kegiatan Agreement on Trade Releated Aspect Of Intelectual Property Rights (Persetujuan TRIPS), yang mana sesuai dengan UU No. 7 Tahun 1994, tentang Pengesahan Agreement Estabilishing the 
World Trade Organization (Persetujuan Pembentukan Organisasi Perdagangan Dunia). Berdasarkan pengalaman selama ini, peran serta berbagai instansi dan lembaga, baik dari bidang pemerintahan maupun bidang swasta serta koordinasi yang baik diantara semua pihak merupakan hal yang mutlak diperlukan guna mencapai hasil pelaksanaan sistem Hak Kekayaan Intelektual yang efektif.

Pelaksanaan sistem Hak Kekayaan Intelektual yang baik bukan saja memerlukan Peraturan Perundangundangan di bidang Hak Kekayaan Intelektual yang tepat, tetapi perlu didukung pula oleh Administrasi, Penegakkan Hukum serta program sosialisasi yang optimal tentang Hak Kekayaan Intelektual (HAKI).

I. Peraturan Perundang-undangan dan KonvensiKonvensi Internasional.

Pelaksanaan Sistem Hak Kekayaan Internasional yang baik dimana mampu melindungi dan memberikan Kepastian Hukum kepada seseorang terkait karya cipta dan karsanya memerlukan suatu perangkat Peraturan Perundang-undangan yang mengatur dengan komprehensif terkait Hak Kekayaan Intelektual tersebut.

Pada saat ini Indonesia telah memiliki Perangkat Peraturan Perundang-undangan di bidang Hak Kekayaan Intelektual yang cukup memadai dan tidak bertentangan dengan ketentuan-ketentuan sebagaimana yang dipersyaratkan dalam persetujuan TRIPS (Agreement on Trade Releated Aspect Of Intelectual Property Rights). Peraturan Perundang-undangan dimaksud mencakup :

a. UU No. 12 Tahun 1997 tentang Perubahan UU No. 6 Tahun 1982 tentang Hak Cipta sebagaimana telah diubah dengan UU No. 7 Tahun 1987 (UU Hak Cipta) yang dalam waktu dekatUndang-Undang ini akan direvisi untuk mengakomodasikan perkembangan mutakhir di bidang hak cipta. b. UU No. 29 Tahun 2000 tentang Perlindungan Varietas Tanaman

c. UU No. 30 Tahun 2000 tentang Rahasia Dagang

d. UU No. 31 Tahun 2000 tentang Desain Industri

e. UU No. 32 Tahun 2000 tentang Desain Tata Letak Sirkuit Terpadu

f. UU No. 15 Tahun 200 I tentang Merek

Di Indonesia, Sistem Perlindungan Merek telah dimulai sejak tahun 196I, sistem perlindungan Hak Cipta dimulai sejak tahun 1982, sedangkan Sistem Paten baru dimulai sejak tahun 1991. Sebelum disempurnakan melalui Peraturan Perundang-undangan yang ditetapkan pada tahun 200I, beberapa waktu yang lalu pada tahun 2007 terhadap ketiga Peraturan Perundang-undangan tersebut telah dilakukan perubahan untuk menyesuaikan dengan kebutuhan dan merupakan Kesepakatan Internasional yang paling komprehensif dan merupakan suatu perpaduan yang unik dari Prinsip-Prinsip Dasar GATT (General Agreement on Tariff and Trade) dengan ketentuan-ketentuan substantif dari KesepakatanKesepakatan Internasional Bidang Hak Kekayaan Intelektual, antara lain : Paris Convention For the Protection of Industrial Property dan Bern Convention For the Protection of Literary and Artistic Works.

Sejalan dengan perubahan berbagai undangundang tersebut di atas Indonesia juga telah meratifikasi Konvensi Internasional di bidang Hak Kekayaan Intelektual yaitu sebagai berikut :

a. Paris Convention For the Protection of Industrial Property dan Convention Estabilishing the World Intelectual Property Organization (Keputusan Presiden No. 15 Tahun 1997 tentang Perubahan atas Keputusan Presiden No. 24 Tahun 1979). 
b. Patent Coorporation Treaty (PCT) and Regulation Under the PCT (Keputusan Presiden No. 16 Tahun 1997).

c. Trademark Law Treaty (Keputusan Presiden No. 17 Tahun 1997).

d. Berne Convention For the Protection of Literary and Artistic Works (Keputusan Presiden No. 18 Tahun 1997)

e. WIPO Copyright Treaty (Keputusan Presiden No. 19 Tahun 1997)

2. Administrasi Hak Kekayaan Intelektual (HAKI)

Di Indonesia secara Institusional, lembaga yang tugas dan fungsi utamanya untuk menyelenggarakan Administrasi Hak Cipta, Hak Paten, Merek, Desain Industri dan Desain Tata Letak Sirkut Terpadu adalah Direktorat Jenderal Hak Kekayaan Intelektual. Direktorat Jenderal Hak Kekayaan Intelektual (semula disebut Direktorat Jenderal Hak Cipta, Paten dan Merek) dibentuk pada tahun 1998. Direktorat Jenderal Hak Kekayaan Intelektual yang baik sebagaimana diharapkan oleh masyarakat, baik yang berasal dari dunia industri dan perdagangan maupun dari institusi yang bergerak di bidang penelitian dan pengembangan.

Jika dibandingkan dengan yang terdapat di negaranegara maju, Direktorat Jenderal Hak Kekayaan Intelektual masih merupakan institusi yang relatif masih muda dan baru, oleh karena itu dapat dimaklumi seandainya dalam melaksanakan tugas dan fungsinya masih dijumpai berbagai macam kendala, sehingga diharapkan Direktorat Jenderal Hak Kekayaan Intelektual sering melakukan pembinaan melalui berbagai program pelatihan yang intensif agar memiliki Sumber Daya Manusia yang memiliki pengetahuan yang cukup memadai guna mendukung peningkatan sistem Hak Kekayaan Intelektual sebagaimana yang diharapkan.
Bahwa dalam rangka untuk lebih meningkatkan pelayanan dan kemudahan bagi masyarakat sejak tahun 2000, pengajuan permohonan hak kekayaan intelektual dapat dilakukan di Kantor-Kantor Wilayah Hukum dan Hak Asasi Manusia. Dimana selanjutnya Kantor-Kantor Wilayah akan menyampaikan permohonan tersebut kepada Direktorat Jenderal Hak Kekayaan Intelektual untuk diproses lebih lanjut. Di samping itu untuk lebih meningkatkan sistem administrasi di bidang Hak Kekayaan Intelektual sekarang ini dengan bantuan World Bank sedang dilaksanakan penyempurnaan sistem otomasi di Direktorat Jenderal Hak Kekayaan Intelektual yang diharapkan dapat lebih menunjang proses administrasi dimaksud.

Khusus untuk Hak Kekayaan Intelektual di bidang varietas tanaman maka administrasinya dikelola oleh Departemen Pertanian tidak seperti bidang-bidang kekayaan intelektual lain yang administrasinya dikelola oleh Direktorat Jenderal Hak Kekayaan Intelektual.

3. Penegakkan Hukum Hak Kekayaan Intelektual

Perlindungan dan Penegakkan Hukum HAKI bertujuan untuk mendorong timbulnya Inovasi, Pengalihan dan Peyebaran Teknologi dan diperoleh manfaat bersama antara penghasil dan pengguna pengetahuan teknologi dengan cara menciptakan kesejahteraan social ekonomi serta keseimbangan antara hak dan kewajiban. Sehingga keterlibatan berbagai pihak secara terkoordinasi dan intensif sangat diperlukan untuk menjamin terlaksananya sistem Hak Kekayaan Intelektual yang diharapkan.

Sesuai dengan keputusan Presiden Nomor 189 Tahun 1998, Kantor Wilayah Hukum dan Hak Asasi Manusia cq. Direktorat Jenderal Hak Kekayaan Intelektual telah ditugasi melakukan koordinasi dengan semua instansi pemerintah yang berkompeten mengenai segala kegiatan dan 
permasalahan dibidang Hak Kekayaan Intelektual. Prinsip-prinsip pokok penegakkan hukum Hak Kekayaan Intelektual (HAKI) dalam TRIPS (Agreement on Trade Releated Aspect Of Intelectual Property Rights):

a. Menetapkan standar minimum untuk perlindungan dan penegakkan hukum HAKI dinegara-negara peserta.

b. Masing-masing Negara peserta harus melindungi warga Negara dari Negara peserta lainnya.

c. Negara-negara peserta diharuskan memberikan perlindungan HAKI yang sama kepada warga Negara peserta lainnya.

d. Penegakkan hukum yang ketat disertai dengan mekanisme penyelesaian perselisihan sengketa yang diikuti dengan hak bagi Negara yang dirugikan untuk mengambil tindakan secara silang.

Dengan berkembangnya hubungan perdagangan Internasional yang semakin global dan pesat sejalan dengan laju pertumbuhan ekonomi ditiap Negara tentunyaakan memberikan dampak dibidang Teknologi, Informasi, Komunikasi dan Transportasi, yang mana berbagai bidang tersebut merupakan factor yang memicu globalisasi Hak Kekayaan Intelektual (HAKI). Dengan demikian HAKI amat penting mendapatkan Perlindungan Hukum karena merupakan karya-karya intelektual yang dihasilkan karena intelektual manusia.

4. Peningkatan Kesadaran Masyarakat

Secara bertahap dan berkesinambungan telah diupayakan sosialisasi mengenai peran Hak Kekayaan Intelektual diberbagai aspek dalam kehidupan sehari-hari seperti kegiatan perindustrian dan perdagangan, investasi, kegiatan penelitian dan pengembangan dan lain sebagainya berbagai masyarakat pun telah dilibatkan dalam kegiatan ini.
Tumbuhnya berbagai sentra Hak Kekayaan Intelektual, Klinik Hak Kekayaan Intelektual dan Pusat Hak Kekayaan Intelektual lain baik yang dimotori oleh Departemen Perindustrian dan Perdagangan, Departermen Pendidikan Nasional, Kantor Menteri Negara Riset dan Teknologi, Perguruan-Perguruan Tinggi dan cukup banyaknya Hak Kekayaan Intelektual menunjukkan telah tumbuhnya kesadaran masyarakat dibidang Hak Kekayaan Intelektual. Disamping itu apresiasi yang positif dari anggota masyarakat juga terlihat dalam wujud pendaftaran karya-karya mereka ke KantorKantor Wilayah Hukum dan Hak Asasi Manusia.

\section{Kebijaksanaan Pemerintah Dalam Melaksanakan Beberapa Ketentuan Dalam Persetujuan TRIPS (Agreement on Trade Releated Aspect Of Intelectual Property Rights)}

Pada prinsipnya semua peraturan dibidang Hak Kekayaan Intelektual telah disusun dengan memperhatikan kepentingan masyarakat dan selaras dengan ketentuan minimum sebagaimana yang dipersyaratkan oleh persetujuan STRIPS (Agreement on Trade Releated Aspect Of Intelectual Property Rights).

I. Pengaturan HAKI dalam TRIPS (Agreement on Trade Releated Aspect Of Intelectual Property Rights)

a. Hak Cipta dan Hak yang berkaitan dengan Hak Cipta

b. Merek Dagang

c. Indikasi Geografis

d. Desain Industri

e. Paten

f. Rahasia Dagang

g. Control of Anti Competitive Practices in Contractual Licences

h. Enforcement

2. Pengaturan Hak Milik Industri
a. Paten
b. Paten Sederhana
c. Desain Industri
d. Merk Dagang, Merek Jasa, Rahasia Dagang
e. Indikasi Geografis

3. Hak Cipta dan Hak-Hak yang Terkait dengan Hak Cipta
a. Karya Seni dan Sastra
b. Gambar
c. Film 
d. Puisi

e. Fotografi

f. Ukiran

g. Software Komputer

h. Data Base

i. Desain Arsitektur

4. Keanggotaan dalam Konvensi Internasional di Bidang HAKI

a. Konvensi Paris untuk Perlindungan Hak Milik Intelektual (Paris Conventions)

b. Traktat Kerjasama Paten (PCT)

c. Traktat KerjasamaMerek (Trade Mark Law Treaty)

d. Traktat Kerjasama WIPO dibidang Hak Cipta (WIPO Copyright Treaty)

5. Hak Kekayaan Intelektual (HAKI) dalam Pengembangan Perekonomian dan Teknologi

a. Perlindungan hokum sebagai insentif bagi Investor, Kreator, Desainer dan Pencipta dengan memberikan Hak khusus untuk mengkomersilkan Hasil dan Kreatifitasnya.

b. Pemerintah wajib menciptakan iklim yang kondusif bagi investor.

c. Mendorong kegiatan-kegiatan penelitian dan pengembangan untuk menghasilkan penemuan baru diberbagai bidang teknologi.

d. Sistem Paten akan memperkaya pengetahuan masyarakat dan akan melahirkan penemupenemu baru.

e. Peningkatan dan Perlindungan HAKI akan mempercepat pertumbuhan industri, menciptakan lapangan kerjabaru, mendorong pertumbuhan ekonomi, meningkatkan kualitas hidup manusia yang memberikan kebutuhan masyarakat luas.

6. Peran dan Tantangan Sistem Hak Kekayaan Intelektual (HAKI) di Masa Depan

a. Menciptakan iklim perdagangan dan investasi yang kompetitif.

b. Meningkatkan perkembangan teknologi

c. Mendukung perkembangan dunia usaha yang kompetitif dan spesifik di pasar global

d. Meningkatkan invensi dan inovasi dalam negeri yang berorientasi ekspor dan bernilai komersial.

e. Mempromosikan sumber daya social dan budaya yang dimiliki.

f. Memberikan Reputasi Internasional untuk ekspor produk lokal yang berkarakter dan memiliki tradisi budaya daerah.
7. Alih Teknologi

Persetujuan TRIPS (Agreement on Trade Releated

Aspect Of Intelectual Property Rights) memang mengatur perlu didukungnya upaya alih teknologi dari Negara Majuke Negara Berkembang. Walaupun demikian dalam pelaksanaannya agar penerapan ketentuan ini dapat lebih efektif dipandang perlu untuk menjabarkannya secara lebih lanjut.

Beberapa ketentuan dalam Peraturan Perundang undangan di bidang Hak Kekayaan Intelektual telah mengakomodasikan ketentuan yang baik secara langsung atau pun tidak langsung mensyaratkan dilaksanakan paten.

Perlu disadari bahwa berapa pun idealnya pengaturan mengenai alih teknologi pada akhirnya segalanya tergantung kepada kemampuan kita sendiri untuk menyempurnakan dan mengembangkan teknologi yang bersangkutan. Oleh karena itu peran serta berbagai instansi yang terkait untuk lebih meningkatkan efektivitas alih teknologi perlu diintensifkan.

\section{Pencapaian}

I. Indonesia telah merubah standar PeraturanHak Kekayaan Intelektual (HAKI) dengan standar minimum ketentuan TRIPS (Agreement on Trade Releated Aspect Of Intelectual Property Rights).

2. Sosialisasi Hak Kekayaan Intelektual (HAKI) yang berkelanjutan melalui Kerjasama Universitas, Instansi Pemerintah dan UKM.

3. Melaksanakan Pemeriksaan Banding Paten dan Merek.

4. Penerimaan Pendaftaran Hak kekayaan Intelektual (HAKI) melalui Kantor Kementerian Hukum dan Hak Asasi Manusia.

5. Pelaksanaan Sistem Otomasi Hak Kekayaan Intelektual (HAKI)

6. Penigkatan Law Enforcement Hak Kekayaan Intelektual (HAKI) yang lebih baik 
7. Peningkatan Kualitas Sumber Daya Manusia

8. Peningkatan dan pemanfaatan Kerjasama Internasional di Bidang Hak Kekayaan Intelektual (HAKI).

\section{KESIMPULAN}

I. Hak Kekayaan Intelektual (HAKI) adalah isu penting bagi Pembuat Keputusan Ekonomi

2. Hak Kekayaan Intelektual (HAKI) adalah alat yang ampuh untuk mendorong pembangunan ekonomi, ilmu pengetahuan, social dan budaya.

3. Pada intinya semua peraturan perundang-undangan dibidang Hak Kekayaan Intelektual telah disusun dengan memperhatikan kepentingan masyarakat dan selaras dengan ketentuan minimum sebagaimana yang dipersyaratkan oleh Persetujuan TRIPS (Agreement on Trade Releated Aspect Of Intelectual Property Rights).

4. Perlunya Perubahan sifat masyarakat yang berorientasi dari Pertanian (statis) kelndustri (dinamis) dan mengarah kepada Budaya Bisnis (kompetitif).

5. Perlunya peran serta berbagai Instansi dan Lembaga, baik dalam bidang pemerintah maupun bidang swasta, serta koordinasi yang baik diantara semua pihak, guna mencapai hasil pelaksanaan Sistem Hak Kekayaan Intelektual (HAKI) yang efektif.

\section{REFERENSI}

Damian, Edy. 20I4. Hak Kekayaan Intelektual. Cet.4. Bandung. Alumni.

Djulaeka. 2014. Konsep Perlindungan Hak Kekayaan Intelektual. Malang. Cita Intrans Selaras.

Djumhana, Muhamad dan R, Djubaedillah. 20I4. Hak Milik Intelektual : Sejarah, Teori dan Praktiknya di Indonesia. Bandung. Citra Aditya Bakti.

Jened, Rahmi. 20I4. Hukum Hak Cipta (Copyright"s Law), Bandung. Citra Aditya Bakti.

Ginting, Elyta Ras. 2012. Hukum Hak Cipta Indonesia Analisis Teori dan Praktik. Bandung. Citra Aditya Bakti.

Hidayah, Khoirul. 2013. Hukum HKI (Hak Kekayaan Intelektual) di Indonesia :Kajian Undang-Undang \& Integrasi Islam. Malang. UIN Maliki Press.

Hery, Firmansyah. 20II. Perlindungan Hukum Terhadap Merek. Yogyakarta. Pustaka Yustisia.

Lindsey, Tim. 20I3. Hak Kekayaan Intelektual Suatu Pengantar. Bandung. Alumni.

Munandar, Haris dan Sally Sitanggang. 2008. Mengenal Hak Kekayaan Intelektual (Hak Cipta, Paten, Merek dan Seluk-beluknya). Jakarta. Penerbit Erlangga.

Purba, Afrillyanna. 2005. TRIPs-WTO dan Hukum HKI Indonesia Kajian Perlindungan Hak Cipta Seni Batik Tradisional Indonesia. Jakarta. Asdi Mahasatya.

Saidin. 20I5. Aspek Hukum Hak Kekayaaan Intelektual (Intelecctual Property Rights). Jakarta. Raja Grafindo Persada.

Subroto, Muhammad Ahkam. 2005. Eksplorasi Konsep Kekayaan Intelektual Untuk Penumbuhan Inovasi. Jakarta. LIPI Press.

Usman, Rachmadi. 2003. Hukum Hak atas Kekayaan Intelektual : Perlindungan dan Dimensi Hukumnya di Indonesia. Bandung. Alumni. 